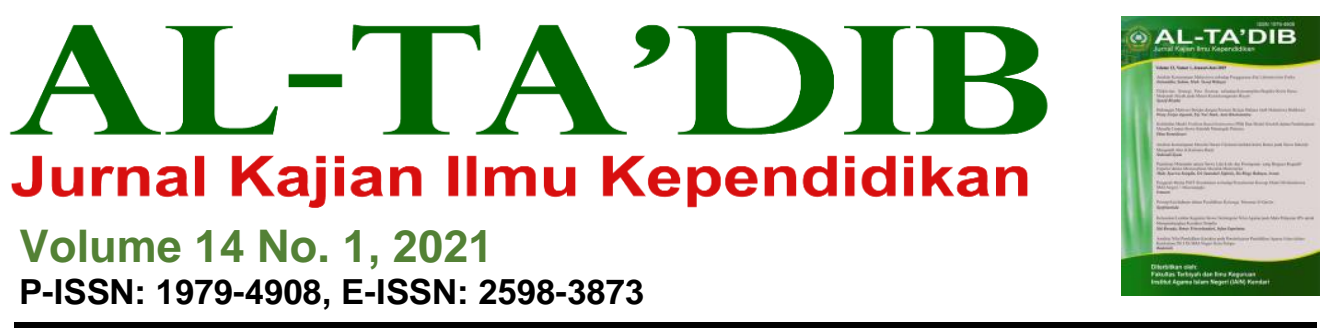

\title{
Meningkatkan Prestasi Belajar Al-Qur'an-Hadis Melalui Metode Demonstrasi pada Siswa Madrasah Aliyah
}

\section{Halwing ${ }^{1}$}

${ }^{1}$ Madrasah Aliyah Negeri 1 Bombana, Indonesia. E-mail: halwing121966@yahoo.com

\begin{tabular}{l} 
ARTICLE INFO \\
\hline Keywords: \\
Al-Qur'an-Hadis subject; \\
demonstration method; \\
learning achievement \\
How to Cite: \\
Halwing. (2021). \\
Meningkatkan prestasi \\
belajar Al-Qur'an-Hadis \\
melalui metode \\
demonstrasi pada siswa \\
madrasah aliyah. Al- \\
Ta'dib: Jurnal Kajian Ilmu \\
Kependidikan, 14(1), 42- \\
52.
\end{tabular}

INFORMASI ARTIKEL

Kata Kunci:

Mata pelajaran Al-Qur'an-

Hadis; metode

demonstrasi; prestasi

belajar

\section{Cara Mensitasi:}

Halwing. (2021).

Meningkatkan prestasi belajar Al-Qur'an-Hadist melalui metode demonstrasi pada siswa madrasah aliyah. Al-Ta'dib: Jurnal Kajian Ilmu Kependidikan, 14(1), 42-52.

\begin{abstract}
This article aims to describe the results of a classroom action research on the learning process using demonstration method and how this method improves students' learning achievement in Al-Qur'an-Hadith subject. The participants of this study were students of class X. Data collection techniques used observation, learning outcomes tests and documentation. Data was analized qualitatively and quantitatively. The results of data analysis showed that demonstration method could trigger students' responses to better learning so that they become more active in the learning process. The results of data analysis indicate that the implementation of demonstration method could improve students' achievement in Al-Quran-Hadith subject.
\end{abstract}




\section{Pendahuluan}

Pendidikan sebagai sebuah kegiatan dan proses aktivitas yang disengaja merupakan gejala ketika masyarakat sudah mulai menyadari pentingnya upaya untuk membentuk, mengarahkan, dan mengatur manusia sebagaimana yang dicita-citakan masyarakat (Gunawan, 2012). Masalah pendidikan dan pengajaran merupakan masalah yang cukup kompleks mengingat banyak faktor yang ikut mempengaruhi, salah satunya adalah faktor guru. Tugas guru adalah menyampaikan materi pelajaran kepada siswa melalui interaksi komunikasi dalam proses belajar mengajar. Guru adalah profesi yang sangat dihormati dan memiliki otonomi besar dalam mengendalikan konten dan arah pembelajaran (Baswedan, 2014). Melalui komunikasi yang dilakukan, guru berupaya memberikan stimulus kepada siswa, sehingga menimbulkan respon dari siswa dalam proses pembelajaran. Agar aktivitas belajar siswa di kelas dapat mencapai hasil belajar yang optimal, stimulus harus dirancang secara menarik dan spesifik sehingga mudah direspon oleh semua siswa dan berdampak pada perolehan hasil belajar maksimal (Darmadi, 2015).

Untuk dapat meningkatkan prestasi belajar serta kualitas pembelajaran siswa, perlu dipilih metode pembelajaran yang sesuai kebutuhan dengan memperhatikan tingkat partisipasi aktif dan kreativitas mereka (Megawanti, 2015). Kegiatan belajar mengajar melibatkan beberapa komponen, yaitu peserta didik, guru sebagai pendidik, tujuan pembelajaran, metode mengajar, dan media. Selain itu, peran seorang pendidik juga tidak kalah penting utamanya terkait bagaimana pendidik mengembangkan potensi kegiatan pedagogiknya dan potensi siswanya dalam rangka mentransfer ilmu pengetahuan agar tujuan pembelajaran dapat dicapai secara optimal (Sani, 2013).

Di dalam kurikulum, mata pelajaran Pendidikan Agama Islam dinyatakan sebagai usaha sadar untuk menyiapkan peserta didik dalam meyakini, memahami, menghayati dan mengamalkan agama Islam melalui kegiatan bimbingan, pengajaran atau latihan dengan memperhatikan tuntunan untuk menghormati agama lain dalam hubungan kerukunan antar umat beragama dalam masyarakat untuk mewujudkan persatuan nasional (Muhaimin \& Ali, 2002). Eksistensi pendidikan agama Islam di tengah masyarakat telah memberikan warna baru bagi konstruksi tatanan nilai dan sosial masyarakat (Halik, 2016). Jika dicermati, proses pembelajaran agama Islam di sekolah selama ini masih didominasi oleh guru, dimana guru masih menjadi sumber utama pengetahuan. Dalam proses pembelajaran, guru seringkali masih menerapkan strategi klasikal dan metode ceramah sebagai metode pembelajaran yang utama. Akan tetapi, dalam beberapa dekade terakhir ini proses belajar mengajar cenderung berorientasi pada pembentukan kompetensi yang relevan dengan tuntutan dunia nyata yang 
meliputi kompetensi pengetahuan, ketrampilan, nilai dan sikap (Setiawati, 2017).

Sebagai bagian integral dari Pendidikan Agama Islam, mata pelajaran Pendidikan Al-Qur'an-Hadis di madrasah aliyah merupakan bagian yang tak terpisahkan dari penanaman nilai-nilai agama Islam. Mata pelajaran AlQur'an-Hadis merupakan unsur mata pelajaran pendidikan agama Islam pada madrasah aliyah dengan tujuan kompetensi agar peserta didik dapat memahami Al-Qur'an dan Hadis sebagai sumber ajaran agama Islam dan mengamalkan isi pandangannya sebagai petunjuk dan landasan dalam kehidupan sehari-hari. Secara subtansial, mata pelajaran Al-Qur'an-Hadis memiliki konstribusi dalam memberikan motivasi kepada peserta didik untuk mempraktekkan nilai-nilai agama dalam mata pelajaran tersebut ke dalam kehidupan sehari-hari (Kementerian Agama, 2004).

Dalam proses belajar mengajar, guru menggunakan berbagai metode yang sesuai dengan kondisi yang ada agar tercipta suatu lingkungan belajar yang efektif dan efisien. Metode yang digunakan diharapkan memiliki dampak terhadap keberhasilan siswa dalam proses belajar mengajar tersebut. Metode yang kurang tepat akan berakibat pada manajemen waktu yang tidak efisien, misalnya. Sementara itu, pengelolaan kelas yang baik dan berkualitas diharapkan dapat menciptakan suasana belajar yang menyenangkan sehingga dapat membantu terjalinnya keakraban antara guru dan siswa serta memudahkan guru dalam mengarahkan siswa, memberi dorongan dan memotivasi semangat belajar dan berprestasi mereka (Mahmudah, 2018).

Prestasi belajar adalah hasil penilaian pendidikan tentang kemajuan prestasi siswa setelah melakukan aktivitas belajar. Artinya, prestasi belajar tidak akan bisa diketahui tanpa melalui proses asesmen dan penilaian formatif maupun sumatif atas hasil aktivitas belajar siswa. Fungsi prestasi belajar bukan saja untuk mengetahui sejauhmana kemajuan siswa setelah menyelesaikan suatu aktivitas, tetapi yang juga sebagai alat untuk memotivasi setiap siswa agar lebih giat belajar, baik secara individu maupun kelompok (Sodik, Sahal, \& Herlina, 2019). Djamarah (1994) mendefinisikan prestasi belajar sebagai hasil yang diperoleh berupa kesan-kesan yang mengakibatkan perubahan dalam diri individu sebagai hasil dari aktivitas dalam belajar. Jika perubahan tingkah laku adalah tujuan yang hendak dicapai dari aktivitas belajar maka perubahan tingkah laku menjadi salah satu indikator yang dijadikan parameter untuk mengetahui kemajuan individu dalam segala hal yang diperolehnya di sekolah. Dengan kata lain, prestasi belajar merupakan kemampuan yang dimiliki oleh siswa sebagai akibat perbuatan belajar atau setelah menerima pengalaman belajar secara kognitif, afektif, dan psikomotorik.

Dalam proses pencapaiannya, prestasi belajar sangat dipengaruhi oleh berbagai faktor. Salah satu faktor utama yang sangat berpengaruh dalam 
keberhasilan pembelajaran adalah keberadaan guru. Mengingat keberadaan guru dalam proses kegiatan belajar mengajar sangat berpengaruh maka kualitas guru harus menjadi salah satu perhatian utama (Syafi'i, Marfiyanto, \& Rodiyah, 2018). Untuk meningkatkan prestasi pembelajaran Al-Qur'anHadits siswa, upaya yang dapat dilakukan adalah menerapkan metode yang tepat dalam pembelajaran. Metode demonstrasi adalah salah satu metode pembelajaran yang efektif dalam meningkatkan hasil belajar siswa bila dibandingkan dengan metode ceramah (Situmorang \& Situmorang, 2013). Sebagai salah satu metode mengajar, metode demonstrasi dilakukan dengan cara memperlihatkan suatu proses pada seluruh kelompok anak didik, misalnya proses tentang cara bekerjanya sebuah alat atau media pembelajaran (Surachmad, 2006).

Hasil penelusuran awal peneliti pada siswa kelas $\mathrm{X}$ di salah satu madrasah aliyah negeri di Sulawesi Tenggara, diperoleh data bahwa hanya $19 \%$ jumlah siswa mencapai nilai KKM 85, dengan jumlah nilai rata-rata kelas hanya mencapai 69,68 untuk mata pelajaran Al-Qur'an-Hadis. Selain itu, berdasarkan hasil wawancara dengan siswa terungkap sekitar $70 \%$ siswa menyatakan bahwa mata pelajaran Al-Qur'an-Hadits cukup sulit untuk dipelajari karena cenderung menggunakan metode hafalan. Guru menyatakan bahwa siswa yang mengalami kesulitan belajar adalah mereka yang cenderung hanya mengingat pembelajaran ketika di kelas saja, sedangkan ketika dilakukan evaluasi seperti ulangan harian, mereka cenderung lupa materi yang teah mereka dapatkan di kelas.

Berdasarkan masalah yang dialami peserta didik di madrasah aliyah tersebut, penulis berasumsi bahwa untuk menarik minat belajar peserta didik terhadap pelajaran Al-Qur'an-Hadis diperlukan pendekatan dengan menggunakan metode pembelajaran yang dapat menciptakan suasana menyenangkan. Salah satu cara yang dapat dilakukan guru dalam menciptakan susasana menyenangkan adalah dengan memilih metode demonstrasi karena di dalam pelajaran Al-Qur'anHadis ada materi yang dapat dipraktekkan, seperti menghafal Al-Qur'an dalam surat pendek pilihan.

\section{Metode Penelitian}

Penelitian ini menggunakan metode penelitian tindakan kelas (classroom action research) atau PTK yang merupakan pencermatan terhadap kegiatan belajar berupa sebuah tindakan yang sengaja dimunculkan dan terjadi dalam sebuah kelas secara bersama (Sudirman \& Maru, 2015). Lokasi penelitian ini dilaksanakan di salah satu madrasah aliyah di Sulawesi Tenggara yang dijadikan sebagai lokus penelitian dalam penerapan model pembelajaran inovatif melalui metode demonstrasi. Partisipan yang terlibat dalam PTK ini adalah siswa kelas X. Waktu pelaksanaan penelitian disesuaikan dengan jam pelajaran Al-Qur'an-Hadis di kelas tersebut. Tahapan PTK ini meliputi 
empat tahap, yaitu: 1) perencanaan (planning), 2) pelaksanaan tindakan (action), 3) pengamatan (observation), dan, 4) refleksi (reflection). Dari siklus ini diharapkan dapat diperoleh data yang dikumpulkan sebagai jawaban dari permasalahan penelitian.

Prosedur pengumpulan data yang digunakan dalam penelitian ini adalah observasi, dokumentasi, dan pengukuran test hasil belajar. Data yang diperoleh dari tindakan yang dilakukan dianalisis untuk memastikan bahwa dengan implementasi pembelajaran metode demonstrasi dapat meningkatkan motivasi dan prestasi belajar siswa. Data kualitatif yang telah direduksi selanjutnya disajikan dengan cara mendeskripsikan dalam bentuk paparan data yang memungkinkan untuk ditarik kesimpulan. Sementara itu, data yang dikumpulkan berupa angka atau data deskriptif diperoleh dari hasil evaluasi menghitung presentase peningkatan.

\section{Hasil dan Pembahasan}

\subsection{Hasil Penelitian}

Hasil PTK ini menunjukkan bahwa pada pelaksanaan pretest, siswa terlihat kurang antusias terhadap materi pelajaran. Mereka terlihat kurang dapat mengikuti kegiatan belajar mengajar dengan baik yang ditunjukkan dari kurangnya rasa ingin tahu mereka terhadap materi yang diberikan. Hasil evaluasi pada saat pretest menunjukkan rata-rata kelas sebesar 69,68. Gambar 1 menunjukkan rata-rata hasil tes sebelum pelaksanaan siklus (sebelum menggunakan metode demonstrasi) dan setelah menggunakan metode demonstrasi (siklus I, II, dan III).

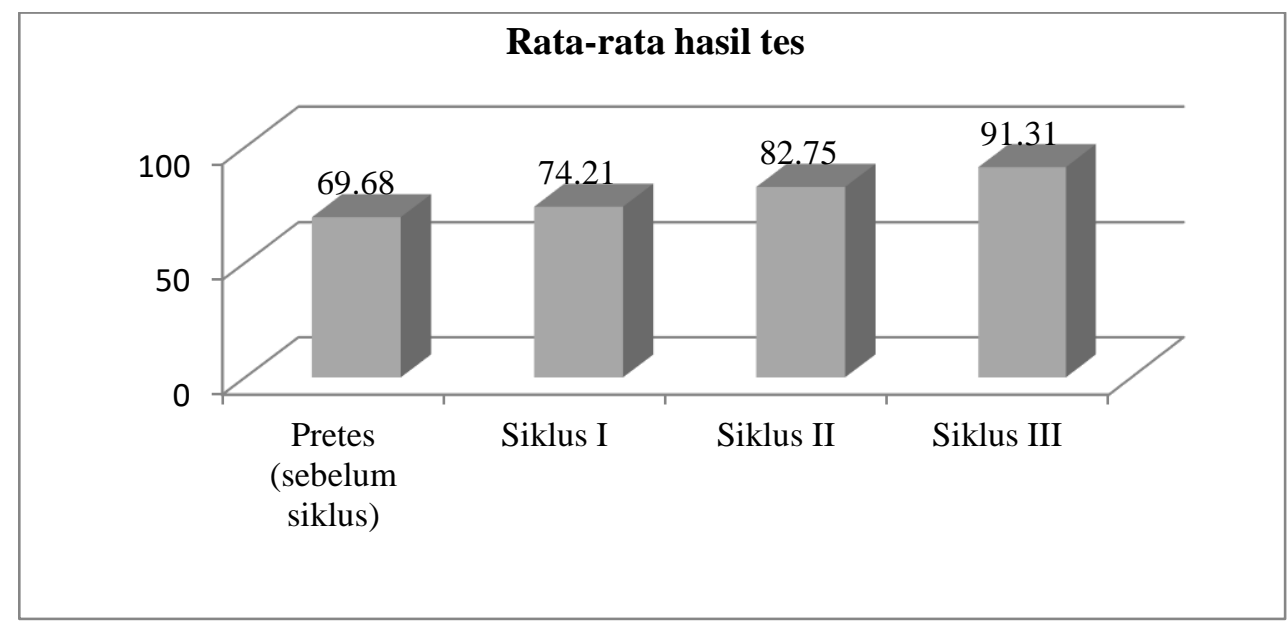

Gambar 1. Grafik rata-rata hasil tes 


\section{Refleksi Siklus I}

Dari hasil pengamatan pada siklus I, kegiatan siswa cukup baik yang dapat dilihat dari antusiasme dan respon positif mereka selama mengikuti kegiatan belajar mengajar. Dalam hal ini, mulai terlihat adanya peningkatan motivasi belajar dibandingkan pada saat pretest. Hal ini terlihat dari aktivitas bertanya siswa. Pada saat pretest, mereka masih malu dan takut salah, sedangkan pada siklus I ini mereka sudah mulai berani bertanya meskipun bobot pertanyaan mereka masih belum seperti yang diharapkan. Selanjutnya, untuk mengetahui tingkat motivasi belajar siswa terhadap materi pelajaran Al-Qur'an-Hadis dan dalam melakukan diskusi, guru memberikan feedback terhadap hasil yang dicapai siswa. Guru juga memberikan tugas untuk mencari secara mandiri hukum bacaan mim sukun dalam surat Al-Kafirun dan Al-Bayyinah dengan batasan waktu sekitar 15 menit sehingga siswa termotivasi untuk berlomba menyelesaikan tugas secara cepat dan tepat.

Gambar 1 menunjukkan bahwa pada siklus ini, hasil tes siswa menunjukkan sedikit peningkatan $(6,50 \%)$ dari 69,68 saat pretest menjadi 74,21 . Hal ini mengindikasikan bahwa penerapan metode demonstrasi dalam proses belajar mengajar Al-Qur'an-Hadis pada siklus I berjalan dengan cukup baik. Hasil pengamatan di kelas menunjukkan antusiasme siswa dalam mengikuti pelajaran, utamanya saat guru melakukan peragaan tajwid serta kegiatan menganalisis hukum bacaan mim sukun yang melibatkan siswa secara aktif. Oleh karena itu, peneliti menyimpulkan bahwa pada siklus I ini, penerapan metode demonstrasi dalam pembelajaran mampu menunjukkan peningkatan prestasi belajar, namun hasil yang dapat diperoleh masih sangat minim sekali.

\section{Refleksi Siklus II}

Pelaksanaan pembelajaran pada siklus II ini tetap sama dengan siklus I. Pada siklus II ini, siswa sudah mulai mengerti dengan model pembelajaran yang diterapkan peneliti. Hasil pengamatan tindakan siklus II menunjukkan bahwa saat peneliti mencoba mengadakan praktek membaca hukum bacaan mim sukun pada akhir pembelajaran, mayoritas siswa dapat melaksanakan aktivitas tersebut dengan baik. Mereka terlihat sangat antusias dan gembira melaksanakan tugas-tugas yang diberikan oleh peneliti. Saat salah satu siswa mempraktekkan hukum bacaan di depan kelas, yang lainnya memperhatikan dengan cermat dan serius.

Gambar 1 memberi gambaran bahwa hasil tes menunjukkan adanya peningkatan hasil belajar siswa $18,75 \%$, dari nilai rata-rata pretest sebesar 69,68 menjadi 82,75. Sementara itu, peningkatan hasil belajar siswa dari siklus I dengan siklus II adalah sekitar $11,50 \%$ dari 74,21 meningkat menjadi 82,75. 


\section{Refleksi Siklus III}

Pada siklus III, siswa sudah paham dengan model pembelajaran yang diterapkan peneliti. Mayoritas siswa sudah mulai terbiasa dengan metode demonstrasi yang diterapkan di kelas $\mathrm{X}$ ini. Pada tahap ini, hasil pengamatan menunjukkan adanya peningkatan hasil belajar siswa yang cukup menggembirakan. Saat proses pembelajaran di kelas, siswa semakin terlihat berpartisipasi aktif dalam bertanya dan mengemukakan pendapat apabila peneliti memberikan permasalahan.

Pada siklus ini, hampir $85 \%$ hasil belajar siswa meningkat. Siswa sudah menunjukkan keterlibatan aktif mereka dalam kegiatan diskusi kelompok dengan aktif mengemukakan pendapat, bertanya dan menjawab pertanyaan. Sebagian siswa sudah dapat menunjukkan kemampuan menyikapi atau memecahkan persoalan dan mengaitkakan materi dengan kehidupan nyata. Hasil tes di siklus ini menunjukkan peningkatan hasil belajar siswa dari nilai pretest sebesar 69,68 meningkat menjadi 91,31, atau terjadi peningkatan sebesar $31,04 \%$. Gambar 2 mengindikasi trend perubahan hasil belajar dari siklus I sampai dengan siklus III. Dari siklus I ke siklus III terjadi peningkatan sebesar 23,04\%.

\subsection{Pembahasan}

Penelitian tindakan kelas ini menggunakan metode demonstrasi sebagai upaya untuk meningkatkan hasil belajar siswa dalam mata pelajaran AlQur'an-Hadis. Pelaksanaan proses belajar mengajar dilakukan sebanyak selama empat kali pertemuan dalam setiap siklus. Metode demonstrasi digunakan dalam PTK ini karena menurut Imron (2016), metode demonstrasi dapat membantu partisipasi aktif siswa di kelas sehingga bisa berdampak pada peningkatan hasil belajar Al-Qur'an-Hadis siswa.

Pada pertemuan pertama, siswa terlihat kurang dapat mengikuti kegiatan melajar mengajar dengan baik karena mereka terlihat bingung dengan apa yang akan mereka lakukan. Hal ini dapat dipahami karena penerapan metode baru di kelas memerlukan waktu agar bisa menjadi hal yang menyenangkan bagi siswa (Astutik, 2012). Kendatipun demikian, antusiasme mereka terhadap tugas yang diberikan cukup baik karena mereka menunjukkan semangat dan kegembiraan selama mengikuti pembelajaran. Selain itu, peneliti berusaha memotivasi siswa agar memahami materi sesuai yang tujuan pembelajaran. Secara umum, hasil penelitian siklus I menunjukkan bahwa siswa cukup termotivasi dalam belajar. Hal ini terlihat dari respon positif dari siswa terhadap penerapan metode demonstrasi yang digunakan dalam penyampaian materi Al-Qur'an-Hadis.

Pada siklus II, melalui penerapan metode demonstrasi ini siswa semakin menunjukkan rasa ingin tahu yang cukup besar. Mereka terlihat semakin antusias dalam mengikuti kegiatan belajar mengajar. Merekapun 
sudah mulai terbiasa mengajukan pertanyaan kepada guru jika ada materi yang belum jelas. Selama kegiatan berlangsung, mereka tampak riang. Hal ini dapat dilihat dari semangat mereka selama belajar. Secara umum, hasil penelitian siklus II menunjukkan peningkatan prestasi belajar siswa terhadap mata pelajaran Al-Qur'an-Hadis.

Pada siklus III ini, peneliti berupaya mengatasi masalah atau kekurangan yang terdapat pada siklus sebelumnya. Melalui kegiatan refleksi ini, peneliti melihat ada peningkatan prestasi belajar yang menggembirakan. Hal ini tampak pada antusiasme siswa yang begitu besar selama pembelajaran. Mereka semangat mengerjakan tugas dalam waktu yang ditentukan, serta gembira dan senang selama mengikuti pembelajaran. Tidak tampak rasa letih di raut wajah mereka, bahkan ketika peneliti memberi kesempatan untuk mengajukan pertanyaan yang direspon secara serentak oleh siswa untuk berebut bertanya kepada guru. Hal ini sejalan dengan yang dikatakan Nasution (2018) bahwa penggunaan metode pembelajaran yang tepat dan sesuai dengan kebutuhan siswa di sekolah dalam proses pembelajaran dapat merangsang pemahaman konsep yang baik pada siswa sehingga dapat melatih mereka dalam mengembangkan kemampuan belajar serta sikap ilmiah mereka.

Berdasarkan pengamatan peneliti, penerapan metode demonstrasi pada mata pelajaran Al-Qur'an-Hadis memiliki dampak positif, yaitu: 1) siswa tidak mengantuk karena mereka termotivasi dengan adanya peragaanperagaan; 2) siswa lebih cepat mengerti dan memahami materi pokok bahasan yang disampaikan dalam kegiatan belajar mengajar; 3) siswa termotivasi untuk lebih giat belajar atau membaca sehingga wawasan mereka menjadi lebih luas; 4) kondisi kelas menjadi lebih hidup karena terbangun interkasi aktif antar guru dengan siswa selama proses pembelajaran; 5) siswa terstimulasi untuk melatih dan mengembangkan daya pikir dan daya ingat mereka; 6) siswa terstimulasi untuk lebih aktif dalam mengikuti proses pembelajaran; 7) siswa terbantu untuk mengingat lebih lama tentang materi pelajaran yang disampaikan; 8) siswa dapat fokus terhadap materi pelajaran dalam waktu yang relatif singkat; 9) siswa dapat lebih memusatkan perhatian dalam belajar; 10) siswa mampu meminimalisir kesalahpahaman karena pembelajaran menjadi lebih jelas dan kongkrit; 11) siswa dapat memperoleh solusi atas permasalahan yang timbul karena mereka ikut berperan langsung.

Sejalan dengan itu temuan pada PTK ini, Syahidah (2020) menegaskan bahwa dengan menerapkan metode demonstrasi pada pembelajaran akan memudahkan siswa mengingat dan memahami materi, memberi pengalaman belajar bagi mereka, tidak hanya pada tataran mental atau aspek pengetahuan saja yang mereka peroleh, namun mereka bisa melihat langsung, serta ikut berpartisipasi aktif dalam kegiatan demonstrasi. Hal tersebut dapat 
membantu mereka untuk mengingat dan memahami materi dengan lebih mudah. Saat mereka diminta untuk menyampaikan materi dengan bahasa mereka pun mereka bisa menyampaikan dengan sangat ringan, mudah dan baik.

\section{Kesimpulan}

Berdasarkan pemaparan hasil analisis data dalam PTK ini, dapat disimpulkan bahwa penerapan metode demonstrasi dalam proses pembelajaran dapat membantu meningkatkan hasil belajar siswa, dalam hal ini pada mata pelajaran Al-Qur'an-Hadis. Hasil PTK ini mengungkapkan bahwa penerapan metode demonstrasi dapat menstimulasi respon siswa terhadap pembelajaran ke arah yang lebih baik. Pelaksanaan metode demonstrasi memudahkan siswa dalam memahami materi pelajaran, khususnya materi pelajaran Al-Qur'an-Hadis yang membutuhkan contoh kongkrit mengenai cara membaca hukum bacaan mim sukun, misalnya. Selain itu, penerapan metode demonstrasi pada pembelajaran Al-Qur'anHadis dapat membantu meningkatkan hasil belajar siswa.

\section{Daftar Pustaka}

Astutik, S. (2012). Meningkatkan hasil belajar siswa dengan model Siklus Belajar (Learning Cycle 5E) berbasis eksperimen pada pembelajaran sains di SDN Patrang I Jember. Jurnal Ilmu Pendidikan Sekolah Dasar, $1(2), 143-153$.

Baswedan, A. R. (2014). Gawat darurat pendidikan di Indonesia. Makalah disampaikan pada pertemuan antara Kementerian dan Kepala Dinas Pendidikan Se-Indonesia di Jakarta.

Darmadi, D. (2015). Hubungan komunikasi guru terhadap prestasi belajar siswa pada mata pelajaran sosiologi di SMU Negeri 5 Samarinda. Jurnal Komunikasi Unmul, 3(3), 211-225.

Djamarah, S. B. (1994). Prestasi belajar dan kompetensi guru. Surabaya: Usaha Nasional.

Gunawan, H. (2012). Pendidikan karakter. Bandung: Alfabeta.

Halik, A. (2016). Paradigma pendidikan Islam dalam transformasi sistem kepercayaan tradisional. AL-ISHLAH: Jurnal Pendidikan Islam, 14(2).

Imron, A. (2016). Peningkatan hasil belajar menggunakan metode 
demonstrasi pada bidang studi Al-Qur'an Hadits MI. MAGISTRA: Media Pengembangan Ilmu Pendidikan Dasar dan Keislaman, 7(1).

Kementerian Agama. (2004). Kurikulum madrasah aliyah dan standar kompetensi mata pelajaran Al-Qur'an Hadits. Jakarta: Kementerian Agama Republik Indonesia.

Mahmudah, M. (2018). Pengelolaan kelas: Upaya mengukur keberhasilan proses pembelajaran. Jurnal Kependidikan, 6(1), 53-70.

Megawanti, P. (2015). Meretas permasalahan pendidikan di Indonesia. Formatif: Jurnal Ilmiah Pendidikan MIPA, 2(3), 1-15.

Muhaimin, M. A., \& Ali, N. (2002). Paradigma pendidikan Islam. Bandung: Remaja Rosda Karya.

Nasution, M. K. (2018). Penggunaan metode pembelajaran dalam peningkatan hasil belajar siswa. Studia Didaktika, 11(1), 9-16.

Sani, R. A. (2013). Inovasi pembelajaran. Jakarta: Bumi Aksara.

Setiawati, N. A. (2017). Pendidikan karakter sebagai pilar pembentukan karakter bangsa. Tesis tidak dipublikasi. Medan: Universitas Negeri Medan.

Situmorang, H., \& Situmorang, M. (2013). Efektivitas metode demonstrasi dalam meningkatkan hasil belajar siswa sekolah menengah kejuruan pada pengajaran sistem koloid. Jurnal Penelitian Bidang Pendidikan, 19(1), 28-36.

Sodik, M., Sahal, Y. F. D., \& Herlina, N. H. (2019). Pengaruh kinerja guru dalam pelaksanaan pembelajaran terhadap prestasi belajar siswa pada mata pelajaran Alquran Hadis. Jurnal Penelitian Pendidikan Islam, 7(1), 97-112. DOI: 10.36667/jppi.v7i1.359

Sudirman, \& Maru, R. (2015). Implementasi model-model pembelajaran dalam bingkai penelitian tindakan kelas. Makassar: Badan Penerbit Universitas Negeri Makassar.

Surachmad, W. (2006). Pengantar interaksi mengajar belajar dasar dan teknik metodologi. Bandung: Remaja Rosda Karya. 
Syafi'i, A., Marfiyanto, T., \& Rodiyah, S. K. (2018). Studi tentang prestasi belajar siswa dalam berbagai aspek dan faktor yang mempengaruhi. Jurnal Komunikasi Pendidikan, 2(2), 115-123.

Syahidah, N. L. (2020). Metode demonstrasi pada pembelajaran PAI (Studi kasus materi penyembelihan hewan dan pengurusan jenazah). EDUDEENA: Journal of Islamic Religious Education, 4(1), 49-58. 